\title{
Students' Experience of Using Storybird in Writing ESL Narrative Text
}

\author{
Siti Mariam Zakaria, Melor Md. Yunus, Nurhuda Mohamad Nazri, Parilah M. Shah \\ Faculty of Education, National University of Malaysia, Bangi, Malaysia \\ Email: sitimariamzakaria@siswa.ukm.edu.my,melor@ukm.edu.my, nurhuda@unikl.edu.my,parila@ukm.edu.my
}

How to cite this paper: Zakaria, S. M., Yunus, M. M., Nazri, N. M., \& Shah, P. M. (2016). Students' Experience of Using Storybird in Writing ESL Narrative Text. Creative Education, 7, 2107-2120. http://dx.doi.org/10.4236/ce.2016.715210

Received: August 2, 2016

Accepted: September 10, 2016

Published: September 13, 2016

Copyright $\odot 2016$ by authors and Scientific Research Publishing Inc. This work is licensed under the Creative Commons Attribution International License (CC BY 4.0).

http://creativecommons.org/licenses/by/4.0/ (c) (i) Open Access

\begin{abstract}
Equipping students with $21^{\text {st }}$ century skills has become the main focus among educators. In line with the Ministry of Education initiatives in transforming the framework of Malaysia Education system, 11 shifts charted are steered to witness the nation stay abreast, if not ahead of global trends. One of the major shifts is to leverage Information and Communications Technology (ICT) in order to escalate quality learning experience in the classrooms across the country. Therefore, preparation of teaching materials with meaningful technology integration is imperative to prepare students for the mastery of $21^{\text {st }}$ century skills. Thus, the assimilation of online tool into teaching and learning of writing skills is stimulating to elevate students' writing competency and motivations along the process. This study aims to identify students' experiences in using digital storytelling tool called Storybird in writing English as a Second Language (ESL) narrative text. Semi-structured interviews and observation are the instruments employed to collect data from 15 diploma students of a private university in Malaysia. The findings show that majority of the respondents reflect their positive experiences in using Storybird in writing ESL narrative text. This study has significant implications to shed some light on the potential use of Storybird as a pedagogical tool for English course.
\end{abstract}

\section{Keywords}

Digital Storytelling, Storybird, ESL Writing, Narrative Text

\section{Introduction}

Possessing bilingual proficiency is a crucial requirement for graduates as employers of multinational companies are seeking for employees with such potential. Despite the number of A's or CGPA's obtained by fresh graduates, majority of them have failed to impress the interviewers when asked to converse in English. They seem to be lacking of 
critical thinking, communication skills and language proficiency in English (MOE, 2012). Realizing the need for the system to keep evolving as to keep updated to the current trends, Ministry of Education (MOE) (2015) has taken a proactive approach in transforming the Malaysian Education System with the launching of National Education Blueprint (2013-2025) and Blueprint for Higher Institution (2015-2025). The Blueprints are the testament for continuous commitment and effort exerted by the Ministry in ensuring that the products of the system are congruent with the expectation of the global market that demands graduates to possess the 21st century skills. Among the $21^{\text {st }}$ century skills that students have to possess are self-direction, creativity, collaboration and innovation (Rotherham \& Willingham, 2010).

With the advancement of technology, students have unlimited access of resources and tools that facilitate language learning (Hashim, Yunus, \& Embi 2016). According to Prensky (2001), millennial students who are known as "Digital Natives" demand a rather different approach of teaching and learning as they have been surrounded by digital tools in their lives, resulting in the change of their thinking patterns. The role of teachers has to evolve upon meeting the demands of these students. Prensky (2007) highlighted how important it was for teachers to utilize technology into the lesson. Despite the fact that students are highly tech-savvy compared to their teachers (Prensky, 2001, 2007), meaningful integration of technology into learning is indispensable. Sadik asserted that "the use of technology can only be effective if teachers themselves possess the expertise to use technology in a meaningful way in the classroom" (p. 487). Many studies have shown the positive effects of using technology in the process of teaching and learning (Yunus, Nordin, Salehi, Embi, \& Salehi, 2013). Since technological innovation has been regarded as a catalyst in learning (Morrison, Ross, \& Lowther, 2009), preparation of teaching materials has to be integrated with technology with the emphasis on incorporating $21^{\text {st }}$ century skills into the lesson. One way of achieving this is through the integration of digital storytelling tool into ESL writing class.

Writing is likely to be a challenging task for ESL students who are easily bored with the conventional approach. It is also a painstaking process for some, especially when they have difficulties in expressing themselves well in writing. In Malaysia, students who are from urban areas and high socio-economy background will not have much trouble in writing as some of them even use English in their daily conversation. In contrast, students who come from rural areas and have limited access to English usually face difficulties in English writing. In general, "writing is the skill that most Malaysian students are least proficient in" (Chitravelu, Sithamparam, \& Teh, 2005: p. 141). The lack of competence in writing cannot be seen as a minor problem, for writing assessment is included in all major examinations in Malaysia. Writing assessment is also part of pre-intake requirement for some of the government and private posts in the country other than attending interview. Thus, the ability of writing bilingually is important. However, the arising issue which needs to be tackled by teachers is on how to motivate the students to write well especially for ESL students. As ESL students are exposed to virtual interaction via social networking sites, they have the tendency to use informal 
language with abbreviated words. This habit may pose challenge for some ESL students to write by using good English structures and wide vocabulary in formal writing assessment.

Nevertheless, with the advent of Web 2.0 tools, writing skills can be enhanced through collaboration with other writers. Young and talented writers would display distinguishing characteristics as they get connected with other avid writers via online writing communities (Olthouse \& Miller, 2012). Besides, teachers can make their writing more interesting with the use of digital storytelling tool. One of digital storytelling tools which gather the writers around the globe is Storybird. Despite numerous literature on digital storytelling (Conrad, 2013; Robin, 2008; Sadik, 2008, Sukovic, 2014), there has been a scarce literature pertaining to writing using Storybird (Herrera, 2013; Menezes, 2012; Wertz, 2014) and a lack of research done in exploring on the students' view towards using Storybird in writing. As highlighted by Mustapha, Rahman, \& Yunus (2010), looking into students' perception is important, for it delves into the classroom realities. Therefore, the research question which acts as a basis for this study is: What is the students' experience in using Storybird? By looking into students' view when they use the application of Storybird in writing a narrative text in the classroom, the use of Storybird as a platform for narrative text is explored in order to achieve the purpose of the study.

\section{Literature Review}

\subsection{Digital Storytelling (DS) and Narrative Writing}

Digital storytelling is a powerful technology tool for $21^{\text {st }}$ century classroom (Robin, 2008). It is a compelling approach in telling stories using multimedia production (Chung, 2007). According to Conrad (2013), digital storytelling emerges as a new form of documenting one's experience through multimedia video creations, blogs, podcasts, activities on social network or other story forms. As the educators around the world are preparing students with $21^{\text {st }}$ century literacy, some opt to use digital storytelling in the classroom as it provides a combination of digital literacy, global literacy, technology literacy, visual literacy and information literacy (Robin, 2008). The notion of Digital Stories is not new as Digital Storytelling movement has started in late 1980s by Joe Lambert and the late Dana Atchley, the co-founders of Centre for Digital Sorytelling (Robin, 2008). Gil (2005) as cited in Sadik (2008) mentioned on the advantages of using digital storytelling in education such as creating real-life situations, engaging students' interest and improving the involvement of students in the process of learning. Studies have shown that digital storytelling is effective in enhancing language learning in a variety of contexts (Thang, Mahmud, \& Tng, 2015). Reinders (2010) affirmed that digital storytelling is a great tool in motivating students to use language inside and outside of the classroom. Sukovic (2014) expressed her strong view that Digital Storytelling promotes a higher order thinking about texts by allowing students to explore new forms of writing and construct their own meaning. On the other hand, Garrard (2011) claimed that there is lack of academic research to indicate that Digital Storytelling can improve 
standards of literacy in the classroom.

Bruner (1991) defines narrative as the organization of human's experience and memories. Narrative may also be thought of as literary fiction, fantasy, pretence or even as lie (Clandinin \& Connelly, 1989). In writing a narrative text, the characters in the story play a very important role. Narrative writing generally is driven by the goals of the characters (Garrard, 2011). Writing a narrative text involves fiction or non-fiction story written based on experience, imagination and observation. Compared to the other genres, narrative writing seems to be the easiest. A good narrative writing usually has an interesting plot and succeeds in arousing the interest of the readers to read from the beginning of the story till the end. The findings of the study by Garrard (2011) revealed that good narrative writing skills is essential in the production of digital story. Nonetheless, she discovered that narrative writing was a difficult activity for EAL (English as an Additional Language) students since they struggled to formulate ideas and use vocabulary in a different language. Even though the students managed to create their digital story, the task was time-consuming. This finding was congruent with a study done by Sadik (2008) whereby students took a long time in learning to use the software and finding appropriate resources for their digital stories project.

In the meantime, Graham and Perin (2007) argued that a lot of youngsters did not learn to write well enough to meet the demands of school or the workplace. They claimed that school was not doing an adequate job in teaching students writing which is considered as a complex skill. Their notion was based on the report by National Commission on Writing (2003) which revealed that many youngsters in the United States did not develop the competence in writing needed at their respective grade. Among the recommendations highlighted by the authors in order to improve adolescent students' writing are to teach them strategies for planning, revising and editing their compositions as well as engaging them in activities which help them gather and organize ideas for their ideas before writing the first draft. Not only that, the authors also emphasized that collaborative activities may improve the quality of writing as students work together to plan, draft, revise and edit their compositions. One of the activities suggested is "developing a visual representation of the ideas before writing" (Graham \& Perin, 2007: p. 467). Since digital storytelling involves visual representation of the ideas, it is a compelling activity to be used in teaching writing. Robin (2008) pointed out that teachers can attract students' interest and engage them into the lesson when digital storytelling is used as an instructional tool upon introducing new topics or presenting new ideas. Hence, digital storytelling is a great tool for teaching ESL narrative text.

\subsection{Storybird in the Classroom}

One of digital storytelling applications or sites which have gained millions of users is Storybird. As shown in Figure 1, Storybird is a very simple and engaging tool as it offers ready-made high quality digital visualization (Pop, 2012). Storybird allows its users to collaborate and share artistic and literacy talent across the globe. Based on the artinspired storytelling, Mark Ury, the founder of Storybird has brought the readers, writers, 


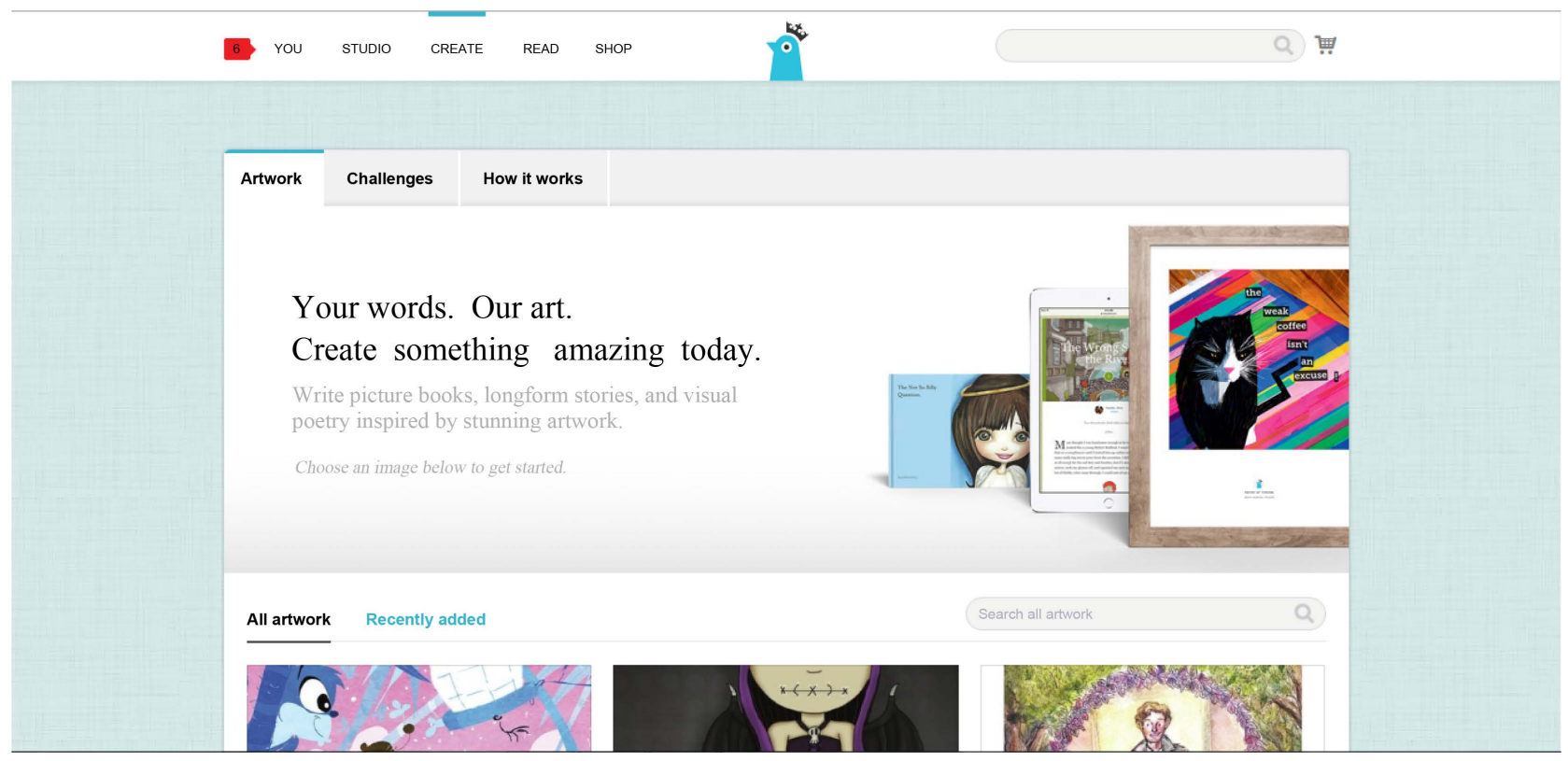

Figure 1. Storybird as an engaging tool.

artists and educators to collaborate and share their talents into the world of virtual storytelling (West, 2013). One of the interesting features of Storybird belongs to its amazing arts. The variety and beautiful images offered in the site enable the users to craft their stories without having to draw pictures. Writers can simply use abundant of free arts by dragging the images in shaping their storyline which eventually change into either picture books or long form books. Picture books function as storyboards where students choose and drag images page by page to suit the storyline. These online books can be shared and read by others. Through collaborative learning, English language proficiency is enhanced (Kwan \& Yunus, 2014). Using Storybird seems to be tempting for students since they can collaborate with other users of Storybird upon completing their story. Students can improve their writing from time to time by reading other books from authors they wish to follow. The reading materials vary in terms of categories, age and format. There are 19 categories to be chosen, depending on the themes and genres which are suitable for preschoolers up to adult either in the format of picture or long form books. Poetry is also available in the site to be read and composed by users. Thus, Storybird enhances critical and creative thinking among the users through reading and writing.

It is suggested that the role of visual is greatly empowered with the application of Storybird in language learning. Jensen (2000) has emphasized the sight impact on the learning process in which "our eyes are capable of registering 36,000 visual messages per hour" (p. 55). Since our brain tends to absorb between 80 and 90 percent of all information visually (Jensen, 2000), Storybird is a great pedagogical tool in promoting reading and writing. The application of Storybird has encouraged the users to create over 10 million picture books for the past few years (Jussel, 2009) as there are avid readers and talented writers who are inspired with the use of arts in storytelling. 
Despite its wonderful features, there is lack of research done on the use of Storybird in writing ESL narrative text (Herrera, 2013; Menezes, 2012; Wertz, 2014). Menezes (2012) claimed that the teachers who were in Language Teacher Master Class in the Polythecnic of Castelo Branco, Portugal had tried out Storybird with their students but there was no specific data collected on the students' own view towards using Storybird. Only implementation and the outcomes of using Storybird by the teachers were highlighted. In the meantime, Wertz (2014) had shared her experience of using Storybird with the fifth and sixth students in narrative writing at Summer Digital Literacy Tool. She asserted that the writing concepts were grounded in traditional school-based literacy but the ideas were conveyed with the use of technology. Apparently, Wertz emphasized on the writing concepts by having her students to go through the stages of writing; brainstorming, writing first draft, revising and editing. She even highlighted how her students worked collaboratively to edit the stories in terms of grammar, spelling and word usage before publishing the stories in Storybird website. Working collaboratively while using Storybird helped her students share experience and create identitites upon producing digital storybooks (Wertz, 2014). In a study conducted by Herrera (2013) between two groups of learners who were undergoing a training course to take the First Certificate in English (FCE) exam, the findings were similar in which both of the groups had shown improvement in terms of vocabulary, specific aspects of the written language and attempts to use more complex structures when collaborative writing strategy was supported with the use of Storybird in writing narrative text. This shows that the use of Storybird enhances active learning among the learners as they work together to construct knowledge and work collaboratively to negotiate content and meaning which is in line with the notion of constructivism (Yunus \& Salehi, 2012).

\section{Method}

\subsection{Research Design}

This study employed a qualitative method which includes semi-structured interview as well as researcher's observational notes in order to have an in-depth understanding on students' experience.

\subsection{Respondents}

15 students of mixed proficiency levels took part in the study. Their proficiency was determined based on their English subject results in the Malaysian Certificate of Education, which is a national examination compulsory to all fifth-year secondary school students. The purpose of having mixed proficiency students is to ensure the study closely resembles the normal classroom setting in Malaysia thus warranting the clarity and significance of the findings. Generally, all schools in Malaysia do not segregate the students according to their English language skills and competencies. Instead, they are ghettoized based on their academic performance or major per se. All respondents in the present study enrolled in Communication English course in which the module is aimed at enabling students to master important skills in writing a variety of technical reports 
and narrative text.

\subsection{Procedures}

Purposive sampling method was employed with the intention of exploring students' experience in using Storybird in writing narrative text. Since none of the respondents had experience in using the tool, hence, a one-day workshop was conducted by the researchers and step-by-step tutorials on how to use the tool were shown. After the respondents were all familiarized with the tool, they were then instructed to sign up for Storybird. Subsequently, they were assigned a writing task based on a "Friendship" theme. In the first 30 minutes, the respondents were asked to complete the task individually. Next, 45 minutes was given to them to work collaboratively among themselves. The social domain of language learning strategy is embedded in the process to minimize inhibiting factors to permit optimization of language learning experience. The researchers observed the respondents and documented observation notes. At the end of the session, the respondents were requested to publish their story online. For the purpose of the interview, 7 respondents including 5 females and 2 males were interviewed regarding their experience of using Storybird in writing a narrative text. It is important to highlight that these respondents were purposively selected for the interview session and the selection was based on their proficiency level in English language. Consequently, the findings will be able to provide significant insights from different perspectives of proficiency levels.

\subsection{Data Analysis}

Semi-structured interviews were conducted in English. Although the respondents had different proficiency level of English, they were able to understand the questions posed to them throughout the interview. This may be partly because they had much exposure towards English listening and speaking in Communication English Course 1. The interviews were then transcribed and analyzed using thematic coding. To retain anonymity, all respondents were coded as R01, R02 and so on. Other than interviews, researcher also looked into the observational notes as to substantiate or contradict findings for interviews.

\section{Findings and Discussion}

This section presents the data collected on the students' experience of using Storybird in writing ESL narrative text as well as discussion on the issues.

\subsection{Students' Experience of Using Storybird as a Platform for Narrative Writing}

Observational notes indicated that all of the respondents succeeded in writing a narrative text or a story within the time-frame except R02 who wrote with the least number of words. The title written by students varied in length. As presented in Table 1, there were noticeable errors pertaining to punctuation and spelling in the title even though 
Table 1. Stories published by students based on the theme of friendship.

\begin{tabular}{lc}
\hline Students & Title \\
\hline R01 & Thank You, My Friend... \\
R02 & SHE \\
R03 & "My Most Generous Friend" \\
R04 & Can I Be Your Umbrella? \\
R05 & "That Little Girl Is My Friend" \\
R06 & "She is my faries" \\
R07 & MATES \\
R08 & everything is okay for you someone who have same personality to create our best friendship \\
R09 & SPECIAL \\
R10 & You Are My Friend, You are My Sunshine \\
R11 & Rain or Shine "I Will Always Be For You" \\
R12 & Lonely New Boy \\
R13 & Newbies In My Life \\
R14 & A Friend in Need a Friend Indeed \\
R15 &
\end{tabular}

students were informed on the spell-checker function in the Storybird. This may suggest that students did not have enough time to proofread their story due to time-constraint. One of the respondents, R11 felt that it was quite difficult for her to generate ideas in sufficient time. To overcome this challenge, respondent chose images as the pre-writing technique. Though not explicitly stated, R11 implied that her writing will be improving from time to time if she keeps on reading online stories shared by other Storybird users since she was impressed with the reading materials which are abundant in the Storybird. Her opinion was also shared similarly with R15 who stated "reading from other authors in Storybird will help me improve my grammar".

Furnished with artistic graphic images, colorful templates and stimulating designs, Storybird captures students' interest in writing as the aforementioned features facilitate the development and elaboration of the storyline. In relation to that, affective strategies were unconsciously employed by the respondents as they become fond towards writing narrative text. This notion is supported by the following comments: "I really like to use Storybird because it is simple and consists of beautiful pictures ... and I will try to write using bombastic words. I love to write in English" (R12) and "I like storybird because it can release my stress. When I feel bored, I can express my feelings through writing" (R13). For example, one of the respondents (R07) commented, "I like Storybird very much because I could not draw well and now I can choose pictures that I like to tell my story". This finding implies that students who are able to write a narrative text will not have difficulties in writing since they have already drafted their stories. This view is supported with the comments: "When writing, if my grammar is not so good, I can just 
use simple vocab and grammar" (R04) and "I have Plan A, Plan B, Plan C when writing. If I can't find suitable pictures, I just change my story plot” (R07). Choosing pictures out of millions of arts is not difficult as they use the search button to find the arts that mostly tally with their story as specified by R13, "At first it was quite difficult because I hardly find suitable pictures but later, when I use the search icon, I can easily find suitable pictures".

Writing via online tool brings a sense of authority to the students, allowing them to feel that their voice is heard. This is supported when R01 pointed that "I can like, share stories with my friends in Storybird" and "Writing online via Storybird helps me to write wisely compared to writing in other social networking sites" (R15). Another important finding is discovered whereby some students prefer working individually. This notion was voiced out by R13, "I'm a shy person. With Storybird, I'm free to write by myself. I'm free to use my own words". R12 felt similarly in which she stated "I can express my feelings where no one will interrupt my writings".

Undeniably, the use of Storybird helps students to develop their interest and a sense of authority in writing, knowing that they can write and express themselves via online tool. Nevertheless, the finding of this study seems to support the notion by Garrard (2011) whereby a few respondents had difficulties to write narrative text as they struggled to generate ideas. This is plausible as some of the respondents are less proficient in English language and in fact, they are low achievers for English subject in the Malaysian Certificate of Education. These students might have faced difficulties in generating and elaborating ideas as a result of poor pre-writing skills such as brainstorming and clustering. Nevertheless, they managed to overcome the obstacle in writing once they chose and arranged the images offered in the Storybird as the pre-writing skills. Their ideas in writing started to flourish while drafting stories based on the images. Therefore, Storybird is a great tool in evoking students' ability to generate more ideas for their respective stories.

\subsection{Students' Engagement through Collaborative Writing}

Students' engagement was analyzed based on the observation on students' contribution in completing the task. In this study, students' contribution was assessed on the number of words written by students within one hour and 15 minutes. According to Malaysian Certificate of Education 1119/1 marking assessment, the length of narrative text written should be about 350 words within one hour. With regards to dragging and arranging pictures while writing online simultaneously with firsthand experience of using Storybird, 11 out of 15 students had written more than 300 words as presented in Figure 2. This has indeed shown that they were highly engaged in completing their task.

Based on the observation, students enjoyed working collaboratively as they were highly engaged in discussion, especially during the pre-writing stage. This finding concurred with the findings gained from the interview as majority of students who were interviewed stated their preference on working collaboratively when completing the task. Students believed that working collaboratively helps them to improve their narrative 
writing. For instance, R07 commented "I prefer working with friends. I can share words or ask my friends to polish my story". Similar opinion was voiced out by R11 and R15 who believed that completing the task collaboratively helps them to boost more ideas in writing. Meanwhile, R01 and R05 shared the same view as they felt that working with friends would help them improving their grammar. R05 claimed that she would write better if she had been given extra time in completing the task since she could discuss with her friends in getting more ideas to write. An example of students working collaboratively is given in Figure 3.

Furthermore, students felt more comfortable to work collaboratively with friends whom they preferred rather than a random respondent assigned by the researchers. Students had been observed to be sitting next to their friends whom they were comfortable with. The reason is because they would not have any boundaries or restrictions to share ideas or ask opinion from friends. One of the participants, R05 stated: "I have an idea but I have difficulties to write sentences, grammar, verbs. So, work with friends can help me to come up with words that I don't know. My friends can help me with my sentences". R11 and R15 argued that working collaboratively allows them to discuss

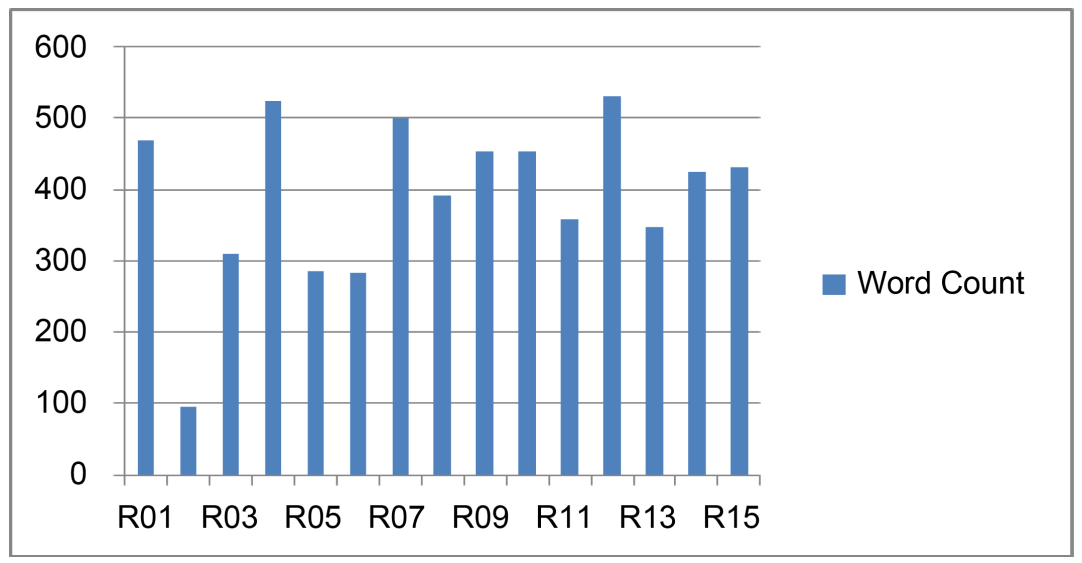

Figure 2. Stories published based on word count.

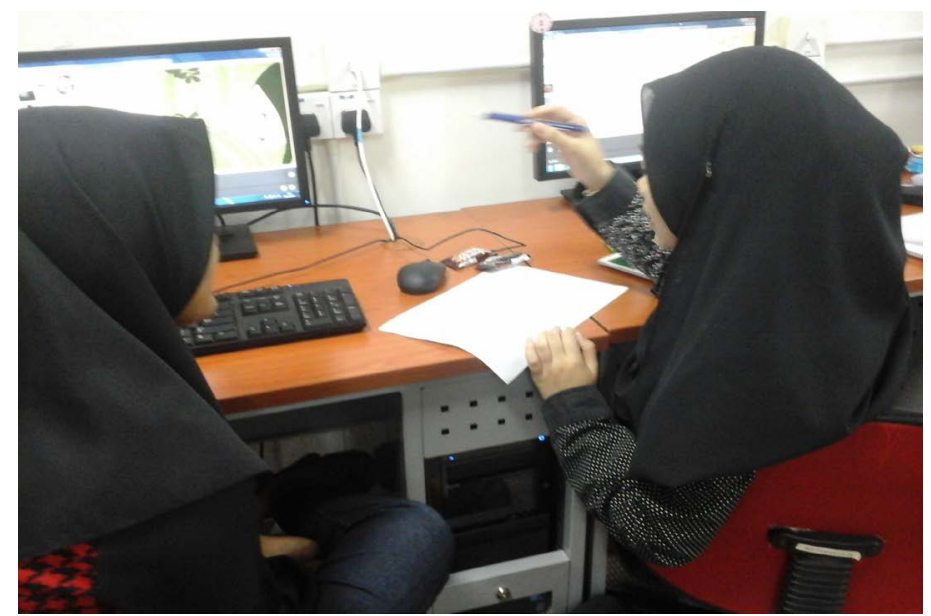

Figure 3. Students work collaboratively upon completing the task. 
with their friends in choosing the right pictures that tally with the story theme. As mentioned by R15, "When my friends help me to choose pictures, I know that it can be a good book" and "My friends would help me choose stories and pictures that are related with theme" (R11). Hence, all of them managed to write stories that tally with the images chosen except R02 who had written her story different than the rest in which she had chosen 10 images with only 95 words. Throughout the observation done during the study, R02 seemed to comfortably work alone rather than working collaboratively with friends.

The above findings seem to be compatible with the findings by Herrera (2013) in which students who worked collaboratively in writing a narrative text when using Storybird had the tendency to improve themselves in vocabulary and were discovered to be writing more complex structures when using Storybird and working collaboratively in writing a narrative text.

\section{Conclusions and Implications}

This paper explores on students' firsthand experience of using Storybird in writing ESL narrative text. In view of students' positive responses towards the use of Storybird as a tool in writing narrative text, teachers should consider utilizing the wonderful features offered by Storybird in order to nurture the habit of writing among the younger generations who are very adept at using technology. Apart from encouraging students to write digital storybook in Storybird, teachers can also assign students to read the materials available on Storybird and incorporate them into lessons. The respondents agree that Storybird is a great tool in helping them to improve their writing skills by reading other online stories shared by other Storybird users. It is suggested that this pedagogical tool has to be meaningfully integrated into the lesson in order to develop literacy skills among students. The success or failure in the utilization of ICT tools in the classroom is largely contributed by the teachers (Shah \& Empungan, 2015). Yunus, Salehi, \& Nordin (2012) stressed on the importance of integrating technology into a pedagogical tool in which it was a more student-centered approach. Indirectly, using Storybird in the lesson helps to instill habit of reading and enhance students' writing skills while promoting active learning among students.

The students' engagement is evident when using Storybird in writing as participants have used variety of images with lengthy texts. They also prefer working collaboratively as they share their feelings and thoughts with their friends in gaining more ideas to write and choosing suitable vocabulary. Nonetheless, it is crucial for them to be taught and guided by teacher during the pre-writing strategies. Teaching pre-writing strategies to students is essential as stated by Graham and Perin (2007) who recommended adolescent students must be taught on planning, revising and editing their compositions.

Despite the limited scope of this study which only explores on students' experience of using Storybird as a digital storytelling tool, writing quality may need to be emphasized in future experimental design and longitudinal study on the effectiveness of Storybird towards students' writing skills. 
Storybird is indeed a great tool in engaging students to write narrative text as it brings students into the world of virtual storytelling with its interesting and beautiful images, ready to be crafted into stories by the users. Despite its wonderful features, aspects of good writing need to be exposed while promoting on the use of Storybird to the students. Thus, teachers are encouraged to exert more efforts in ensuring the students to receive quality education while seeking ways on transforming teaching and learning innovatively. Hence, the initial goal to produce students with the mastery of $21^{\text {st }}$ skills will be realized in the near future.

\section{Acknowledgements}

The researcher would like to thank the respondents and interviewees for providing rich and informative insights for the purpose of this study.

\section{References}

Bruner, J. (1991). The Narrative Construction of Reality. Critical Inquiry, 18, 1-21. http://www.jstor.org/stable/1343711 http://dx.doi.org/10.1086/448619

Chitravelu, N., Sithamparam, S., \& Teh, S. C. (2005). ELT methodology: Principles and Practice. Shah Alam: Penerbit Fajar Bakti.

Chung, S. K. (2007). Art Education Technology: Digital Storytelling. Art Education, 60, 17-22.

Clandinin, D. J., \& Connelly, F. M. (1989). Narrative and Story in Practice and Research. http://eric.ed.gov/?id=ED309681

Conrad, S. K. (2013). Documenting Local History: A Case Study in Digital Storytelling. Library Review, 62, 459-471. http://dx.doi.org/10.1108/LR-02-2013-0013

Garrard, D. (2011). A Case Study to Evaluate the Effectiveness of Digital Storytelling as a Narrative Writing Tool. https://ulir.ul.ie/bitstream/handle/10344/1818/2011_Garrard\%2cD.pdf?sequence=6

Graham, S., \& Perin, D. (2007). A Meta-Analysis of Writing Instruction for Adolescent Students. Journal of Educational Psychology, 99, 445-476. http://dx.doi.org/10.1037/0022-0663.99.3.445

Hashim, H., Yunus, M. M., \& Embi, M. A. (2016). Pre-University English as Second Language (ESL) Learners' Attitude towards Mobile Learning. Creative Education, 7, 1147-1153. http://dx.doi.org/10.4236/ce.2016.78119

Jensen, E. (2000). Brain-Based Learning. San Diego, CA: Brain Store.

Jussel, A. (2009). Storybird Kids Online Book Community Hatches Creative Fledglings. http://www.shapingyouth.org/?p=8341

Kwan, L. S., \& Yunus, M. M. (2014). Group Participation and Interaction in ESL Wiki Collaborative Writing among Malaysian Gifted Students. Asian Social Science, 11, 59.

Menezes, H. (2012). Using Digital Storytelling to Improve Literacy Skills. Proceedings of the IADIS International Conference On Cognition \& Exploratory Learning in Digital Age, 299-301.

Ministry of Education (MOE) (2012). Preliminary Report: Malaysia Education Blueprint 20132025. www.moe.gov.my/userfiles/file/PPP/Preliminary-Blueprint-Eng.pdf

Ministry of Education (MOE) (2015). Malaysia Education Blueprint 2015-2025 (Higher Education).

http://www.moe.gov.my/cms/upload_files/files/3_\%20Malaysia\%20Education\%20Blueprint $\% 2$ 
02015-2025\%20(Higher\%20Education).pdf

Morrison, G. R., Ross, S. M., \& Lowther, D. L. (2009). Technology as a Change Agent in the Classroom. In L. Moller, \& D. M. Harvey (Eds.), Learning and Instructional Technologies for the 21st Century (pp. 1-23). Berlin: Springer. http://dx.doi.org/10.1007/978-0-387-09667-4_9

Mustapha, S. M., Rahman, N. S. N. A., \& Yunus, M. M. (2010). Perceptions towards Classroom Participation: A Case Study of Malaysian Undergraduate Students. Procedia-Social and Behavioral Sciences, 7, 113-121. http://dx.doi.org/10.1016/j.sbspro.2010.10.017

Olthouse, J. M., \& Miller, M. T. (2012). Teaching Talented Writers with Web 2.0 Tools. Teaching Exceptional Children, 45, 6-14. http://dx.doi.org/10.1177/004005991204500201

Pop, A. (2012). Enhancing English Language Writing and Speaking through Digital Storytelling. In M. Vlada, G. Albeanu, \& D. M. Popovici (Eds.), 7th International Conference on Virtual Learning (ICVL 2012) (pp. 453-458). Romania: Editura Universitatii din Bucuresti.

Prensky, M. (2001). Digital Natives, Digital Immigrants Part 1. On the Horizon, 9, 1-6. http://dx.doi.org/10.1108/10748120110424816

Prensky, M. (2007). How to Teach with Technology: Keeping Both Teachers and Students Comfortable in an Era of Exponential Change. Emerging Technologies for Learning, 2, 40-46.

Ramirez, Y. E. H. (2013). Writing Skill Enhancement when Creating Narrative Texts through the Use of Collaborative Writing and the Storybird Web 2.0 Tool. Colombian Applied Linguistics Journal, 15, 166-183.

Reinders, H. (2010). Digital Storytelling in the Foreign Language Classroom. http://hdl.handle.net/10652/2496

Robin, B. R. (2008). Digital Storytelling: A Powerful Technology Tool for the 21st Century Classroom. Theory into Practice, 47, 220-228. http://dx.doi.org/10.1080/00405840802153916

Rotherham, A. J., \& Willingham, D. T. (2010). “21st-Century” Skills. American Educator, 34, 1720.

Sadik, A. (2008). Digital Storytelling: A Meaningful Technology-Integrated Approach for Engaged Student Learning. Educational Technology Research and Development, 56, 487-506. http://dx.doi.org/10.1007/s11423-008-9091-8

Shah, P. M., \& Empungan, J. L. (2015). ESL Teachers' Attitudes towards Using ICT in Literature Lessons. International Journal of English Language Education, 3, 201-218. http://dx.doi.org/10.5296/ijele.v3i1.7158

Sukovic, S. (2014). ITell: Transliteracy and Digital Storytelling. Australian Academic \& Research Libraries, 45, 205-229. http://dx.doi.org/10.1080/00048623.2014.951114

Thang, S. M., Mahmud, N., \& Tng, C. K. C. A. (2015). Digital Storytelling as an Innovative Approach to Enhance Learning Mandarin as a Second Language. Journal of E-Learning and Knowledge Society, 11, 11-25.

Wertz, J. A. (2014). Bitstrips and Storybird: Writing Development in a Blended Literacy Camp. Voices from the Middle, 21, 24-32.

West, M. (2013). The Storybird Has Flown the Nest. The Literary Platform. http://theliteraryplatform.com/magazine/2013/03/the-storybird-has-flown-the-nest/

Yunus, M. M., \& Salehi, H. (2012). The Effectiveness of Facebook Groups on Teaching and Improving Writing: Students' Perceptions. Journal of Education and Information Technologies, 1, 87-96.

Yunus, M. M., Nordin, N., Salehi, H., Embi, M. A., \& Salehi, Z. (2013). The Use of Information and Communication Technology (ICT) in Teaching ESL Writing Skills. English Language Teaching, 6, 1-8. http://dx.doi.org/10.5539/elt.v6n7p1 
Yunus, M. M., Salehi, H., \& Nordin, N. (2012). ESL Pre-Service Teachers' Perceptions on the Use of Paragraph Punch in Teaching Writing. English Language Teaching, 5, 138-146.

http://dx.doi.org/10.5539/elt.v5n10p138

\section{Submit or recommend next manuscript to SCIRP and we will provide best service for you:}

Accepting pre-submission inquiries through Email, Facebook, LinkedIn, Twitter, etc.

A wide selection of journals (inclusive of 9 subjects, more than 200 journals)

Providing 24-hour high-quality service

User-friendly online submission system

Fair and swift peer-review system

Efficient typesetting and proofreading procedure

Display of the result of downloads and visits, as well as the number of cited articles

Maximum dissemination of your research work

Submit your manuscript at: http://papersubmission.scirp.org/ 